O. G. Dudko

Bukovynian State Medical University, Chernivtsi

\title{
MANAGING “TRAUMATOLOGY AND ORTHOPEDICS” EDUCATIONAL COURSE FOR FOREIGN STUDENTS IN BUKOVYNIAN STATE MEDICAL UNIVERSITY
}

\author{
О. Г. Дудко \\ ВДНЗУ “Буковинський державний медичний університет”, м. Чернівці \\ ОРГАНІЗАЦІЯ НАВЧАЛЬНОГО КУРСУ “ТРАВМАТОЛОГІЯ ТА \\ ОРТОПЕДІЯ” ДЛЯ ІНОЗЕМНИХ СТУДЕНТІВ У БУКОВИНСЬКОМУ \\ ДЕРЖАВНОМУ МЕДИЧНОМУ УНІВЕРСИТЕТІ
}

The aim of the work - to analyze tutorial process and to improve the quality of education for English speaking students at "Traumatology and Orthopedics” course.

The main body. Paper presents analysis of tutorial process on "Taumatology and Orthopedics" students of foreign faculty of Bukovynian State Medical University. Peculiarities of theoretical and practical study were described. It was estimated that main problems are lack of tutorial hours that were given for learning the discipline, the quantity and quality of English textbooks and methodical instructions are very low. Problems with patient's curation are related with low level of Ukrainian language and big number of students in groups, that complicates individual approach to mastering practical skills. To resolve the abovementioned problems the distant educational course of "Traumatology and Orthopedics" was introduced. Decreasing number of students in the groups and involvement them to participate in urgent duties will improve the level of theoretical and practical knowledge, motivation and enquiring of students in Traumatology and Orthopedics and will make educational process more individually oriented. Another perspective goal is to compile and publish quality English textbooks and handbooks on "Traumatology and Orthopedics".

Conclusions. Significant improvement of theoretical knowledge and developing the "orthopedics focus" can be achieved with application of modern distant internet-based learning technologies that helps students to improve practical skills as well. On the other hand solving number of problems, as preparing and publishing quality textbooks and methodical instructions on "Traumatology and Orthopedics" course in English, improving website of distant learning, decreasing number of students in groups will improve the quality of learning the discipline.

Key words: traumatology and orthopedics; tutorial process; foreign students.

Мета роботи - провести аналіз навчального процесу англомовних студентів та покращити якість вивчення травматології та ортопедії.

Основна частина. Проведено аналіз навчального процесу з дисципліни “Травматологія та ортопедія” студентів іноземного факультету Буковинського державного медичного університету, наведено особливості їх теоретичної і практичної підготовки. Визначено, що основними перешкодами є недостатня кількість навчальних годин, що відводяться для дисципліни, брак навчальної літератури англійською мовою та її якість, труднощі при курації хворих пов’язані з недостатнім знанням української мови іноземцями, велика кількість студентів у групах, що утруднює індивідуальний підхід при проведенні практичних занять. Створення сервера дистанційного навчання й електронного навчального курсу “Травматологія та ортопедія” покращило навчальний процес. Зменшення кількості англомовних студентів у групах та залучення їх до ургентних чергувань дозволять значно покращити рівень теоретичної і практичної підготовки, посилити мотивацію і зацікавленість студентів, сприятимуть індивідуальному підходу до їх навчання. Перспективними є також підготовка і видавництво власної навчально-методичної літератури англійською мовою.

Висновки. Значного покращення теоретичних знань студентів та розвитку їх ортопедичної спрямованості можна досягти, застосовуючи сучасні технології дистанційного навчання з застосуванням Інтернету, що, у свою чергу, покращить оволодіння студентами практичними навичками. 3 іншого боку, вирішення ряду проблем, таких, як видавництво якісних підручників та навчально-методичних посібників з травматології та ортопедії англійською мовою, удосконалення веб-сайту дистанційної освіти, зменшення кількості студентів у групах, також значно покращить якість вивчення дисципліни.

Ключові слова: травматологія та ортопедія; навчальний процес; іноземні студенти.

Introduction. 15 years ago Bukovynian State Medical University started to teach foreign students in Eng-

(c) O. G. Dudko lish. This fact allowed students from many countries around the world to apply the university. The amount of English speaking students exceeds 1500 and is 
progressively increasing every year. Most of students come from India, Middle East, some African countries, North America with big population and relatively small amount of highly qualified medical specialists [1]. The vast majority of students are studying according educational program "General Medicine” that includes "Traumatology and Orthopedics" on fifth year. In autumn semester 2017-2018 educational year there were 216 students, $48 \%$ more than previous year. Therefore, we are searching the ways to make educational process more effective, to reveal student's level of knowledge in quick and objective way.

The aim of the work - to analyze tutorial process and to improve the quality of education for English speaking students at "Traumatology and Orthopedics' course.

The main body. "Traumatology and Orthopedics" educational course (90 tutorial hours - 10 lecture hours, 40 hours for practical classes) is held for students that have learned already such important disciplines as Anatomy, Histology, Physiology, Pharmacology and Radiology. Lectures, that are considered to be the core of educational process, have information about main principles of examination patients with injuries of locomotor system, advanced approaches for diagnostics and treatment. On the other hand, most complicated for self-learning topics, such as "Regeneration of bone tissue”, "Principles of treatment orthopedic patients”, “Traumatic illness. Polytrauma: combine injuries - clinical and diagnostic signs, treatment”, "Closed and open fractures", "Gunshot fractures", "Traumatic osteomyelyties", "Inflammation, beneath and malignant tumor diseases of locomotor's system clinical and diagnostic signs, treatment” were selected for lectures as well.

One of the urgent tasks to improve tutorial-methodological process in High Medical Institutions is publishing of quality textbooks and methodical instructions. The rate of supply with educational literature for Ukrainian speaking students is $42 \%$ (for textbooks) and $21 \%$ for methodical instructions. It is considerably less for English speaking students, though it hasn't been estimated yet. The amount of published tutorial materials for students in foreign languages is $22.3 \%$ (1372 of 6134 issued within 2012-2016) [2].

40 out of 90 educational hours (44.4\%) are scheduled for self-learning, and we have to point that quality of students' self-education depends a lot from the textbooks and methodical instructions issued in English and their availability for students. There are two ways to improve this point: students can buy books for their own cost (that is a common practice for many universities around the world) or University can buy textbooks and subscribe for scientific journals that are published in English. Both options have to be used but it is quite expensive to supply every student with a textbook (printed usually abroad), considering the fact that amount of students for this year is more than two hundreds, with expected three hundreds and more later. The price for tutorial literature varies from one hundred to five-six hundred US dollars [3]. On the other hand, if some students would like to buy textbooks they have to keep in mind that in Ukrainian bookshops scientific and tutorial literature in English is practically absent. Another option is to buy books online or take them from home. And here we can expect another problem - students usually doubt which book to buy. We analyzed the amount and quantity of "Orthopedic and Oraumatology" textbooks in English that are available for students in our library and those that were brought with students. Some of Indian books are really great, topics are well described, chapters are written in easy and understandable way, and fracture locations are nicely illustrated with drawings and X-rays. Some other books are very complicated and hard for understanding not only for students, but also for experienced specialists. So, in our opinion, at least one issue of textbook on "Orthopedic and Traumatology” from various publishers should be present in the University library to make it possible to review and chose more suitable books, and recommend them for students.

The other way to improve the state of things is to prepare and develop our own printed and electronic tutorial materials. So, now we are preparing for publishing textbook for 5 year students "Diagnostic and treatment algorithms and clinical cases on traumatology and orthopedics”. E-learning technology is considered to be very perspective too. Due to rapidly growing technological progress, computer technologies and Internet nowadays, the way to search the information become very quick and convenient. The simplest example are various search engines (Google, Yahoo, Yandex, etc) that allow every student getting information within seconds just typing "key words" on their phone or tablet. The information can be presented not only as text (*.txt, *.doc, *.rtf, *.html, *.pdf files), but as slides of electronic presentation (*.ppt, *.pptx, *.pdf files), audio and video files, pictures and diagrams (*.jpg, *.tft, *.png, etc). It looks like the Internet forms the ideal surrounding for self-e-learning but in reality a problem of choosing the necessary informa- 
tion stands in front of every student. The search system usually finds thousands of hyperlinks. Such amount of information is practically impossible to review and it is hard for student to choose correct and important links. Internet search system arranges information in such way that most visited websites are shown first. Most visited and most important - are two different things, as websites are visited mostly by non-medical internet users and they contained simplified, incorrect and sometimes grossly twisted information without special medical terminology, thus such information is not acceptable for self-e-learning students of Medical Universities and training a specialist in "Traumatology and Orthopedics".

So, a powerful electronic tutorial resource has been developed in 2011 on the base of Moodle website of the University and includes two main resources "Traumatology and Orthopedics" and "Orthopedics MCI". The program contains plan for practical classes and lectures, reference book for students, tutorial and teaching information that students need for self-learning (questions for discussion, shot abstract on every clinical tasks, tests, hyperlinks on tutorial videos, presentations, graphs and $\mathrm{X}$-rays of different fractures). All tutorial materials are arranged according to educational program and methodical recommendations of Traumatology and Orthopedics Department of O. Bohomolets National Medical University of Ukraine [4]. More than 100 hyperlinks for teaching videos are included in the course that highlight basic principles of diagnostics, classification of injuries and diseases of locomotor system, indications to use additional methods of diagnostics, rare clinical cases and peculiarities of their treatment and diagnostics. Use of educational multimedia materials for self-learning, due to their simplicity and availability, significantly improves theoretical knowledge of students [5].

Within practical classes students study the principles of first medical aid for patients with injuries and fractures - how to apply properly factory-produced splints, to stop bleeding, to apply various bandages. Later students can train themselves to immobilize fractures using the set of Crammer, Thomas and Ditherix splints. Students also get practical knowledge in use of immobilization and functional methods of treatment patients with fractures of extremities. They help to apply plaster bandages, to mount system of continuous skeletal traction (learn to determine the place for $\mathrm{K}$-wire insertion in various segments, the technique of procedure and how to use the special instruments - CITO (Central Institute of Traumatology and Or- thopedics) and Kirshner traction bow, K-wire tension device, electric drill). Another diagnostic-treatment manipulation that students are taught is puncture of joints that is usually done in cases of hemarhtroses and synovitis under local anesthesia. Students learn main principles of anesthesia, types of suitable anesthetics, puncture technique of big joints. Later within practical classes when a topical patient is admitted to the hospital student can take part in this manipulation and then perform it by himself. So, usually every student at the end of the semester can get some practical experience according to approved list of practical skills. Another problem is big amount of students in academic groups (10-13 students) compeering with amount of patients that apply for medical help. This can be partially resolved with involving some students, especially those who is going to become orthopedic surgeon, to take part in urgent duties.

Communication between doctor and patient is an important part of diagnostic and treatment process. Within questioning student can collect patients complains, important data from anamnesis morbi - violence and time of injury, first medical aid - transport immobilization of fracture, application of tourniquet or pressure bandage to stop the bleeding for open injuries.

Making the correct diagnosis and further treatment depends a lot from the quality of communication. It causes some difficulties, as it requires from foreignstudent proper level of fluency in Ukrainian - the language that patient speaks. Teaching courses of Ukrainian language, which were organized on previous courses, can somehow resolve the problem. As well as the fact that students learn "Traumatology and Orthopedic" on their fifth year, so within four years foreigners' can socialize with native Ukrainians and improve their Ukrainian language. There is not a rare case when patient can talk English well and that helps a lot for foreign students. But in the most of the cases patient's curatio is performed with individual supervision by the teacher when latter controls and corrects examination process, helps a student and a patient to understand each other.

Also improving the quality of this practical stage of learning requires decreasing number of students in groups to 5-6 persons.

Conclusions. Significant improvement of theoretical knowledge and developing the "orthopedics focus" can be achieved with application of modern distant internet-based learning technologies that helps students to improve practical skills as well. On the other hand solving number of problems, as preparing and 
publishing quality textbooks and methodical instructions on "Traumatology and Othopedics" in English, improving website of distant learning, decreasing num-

\section{List of literature}

1. Murray Christopher J. L. The State of US Health, 1990-2010. Burden of diseases, injuries, and risk factors / Christopher J. L. Murray // JAMA. - 2013. - Vol. 310. No. 6. - P. 591-608.

2. Мельник I. В. Навчально-методичне забезпечення підготовки студентів у вищих навчальних закладах МO3 України: стан та першочергові завдання / I. В. Мельник, М. О. Поліщук // Медична освіта. - 2017. - № 3. C. 13-21.

3. Ruedi T. P. AO Principles of fracture management / Thomas P. Ruedi, Richard E. Buckley, Christopher G. Moran. - 2nd Ed. - Thieme, 2007. - 1103 p.

\section{References}

1. Murray Christopher, J.L. (2013). The State of US Health, 1990-2010. Burden of diseases, injuries, and risk factors. JAMA, 310 (6), 591-608. doi:10.1001/jama.2013.13805.

2. Melnyk, I.V., \& Polishchuk, M.O. (2017). Navchalnometodychne zabezpechennia pidhotovky studentiv u vyshchykh navchalnykh zakladakh MOZ Ukrainy: stan ta pershocherhovi zavdannia [Educational and methodical supply of students' training in higher education institutions of Ministry of Healthcare of Ukraine: state and primary tasks]. Medychna Osvita - Medical Education, 3, 13-21 [in Ukrainian]. doi: 10.11603/me.2414-5998.2017.3.7773.

3. Ruedi, T.P., Buckley, R.E., \& Moran, C.G. (2007). AO Principles of Fracture Management [2nd Ed.]. Thieme.

4. Buryanov, O.A. (Ed.). (2007). Traumatology and Orthopedics Manual. Medicine. ber of students in groups will improve the quality of learning the discipline.

4. Buryanov O. A. Traumatology and orthopedics manual / O. A. Buryanov. - Kyiv : Medicine, 2007. - 216 p.

5. Дудко О. Г. Застосування сучасних комп’ютерних технологій для дистанційного вивчення дисципліни “Травматологія та ортопедія” англомовними студентами / О. Г. Дудко // Досягнення і перспективи впровадження кредитно-модульної системи організації навчального процесу у вищих медичних (фармацевтичному) навчальних закладах України : матеріали Всеукр. навч.-наук. конф. 3 міжнар. участю, 15-16 трав. 2014 р. : у 2 ч. Тернопіль : ТДМУ, 2014. - Ч. 2. - С. 96-97.

5. Dudko, O.G. (2014). Zastosuvannia suchasnykh kompiuternykh tekhnolohii dlia dystantsiinoho vyvchennia dystsypliny “Travmatolohiia ta Ortopediia” anhlomovnymy studentamy [Application of modern computer-based technologies for distant learning "Traumatology and Orthopedics" for English speaking students]. Dosiahnennia i perspektyvy vprovadzhennia kredytno-modulnoi systemy orhanizatsii navchalnoho protsesu u vyshchykh medychnykh (farmatsevtychnomu) navchalnykh zakladakh Ukrainy-Achievements and Prospectives of Implementation the credit-transfer educational process system in higher medical (pharmaceutical) educational institutions of Ukraine: Proceedings of the international Scientific Conference with International Participation, 2, (pp. 96-97). Ternopil: TDMU [in Ukrainian].

E-mail address for correspondence: dudko.oleksii@bsmu.edu.ua 